\title{
The Generation Rate and Composition of Municipal Solid Waste During the Asian Games XVIII at Jakabaring Sport City Palembang
}

\author{
Dwi Aisyah Ananda ${ }^{1}$, Febrian Hadinata ${ }^{1,}$, , Ika Juliantina ${ }^{1}$, Jalo Hasintongan Pardede ${ }^{2}$ \\ ${ }^{1}$ Faculty of Engineering, University of Sriwijaya, Palembang, Indonesia \\ ${ }^{2}$ Asian Games XVIII Task Force, Housing and Settlement Area Office of South Sumatra Province, Palembang, Indonesia
}

Email address:

anandadee.ad@gmail.com (D. A. Ananda), febrian.hadinata $a$ yahoo.co.id (F. Hadinata)

${ }^{*}$ Corresponding author

\section{To cite this article:}

Dwi Aisyah Ananda, Febrian Hadinata, Ika Juliantina, Jalo Hasintongan Pardede. The Generation Rate and Composition of Municipal Solid Waste During the Asian Games XVIII at Jakabaring Sport City Palembang. Journal of Civil, Construction and Environmental Engineering. Vol. 4, No. 2, 2019, pp. 42-47. doi: 10.11648/j.jccee.20190402.11

Received: April 12, 2019; Accepted: June 2, 2019; Published: June 12, 2019

\begin{abstract}
Jakabaring Sport City is an integrated sports area of $325 \mathrm{Ha}$, consisting of sports and residential facilities. During the sporting event, the volume of municipal solid waste (MSW) from this region increases along with the number of visitors and athletes who are active in the region. This study aims to measure the generation rate and composition of MSW in the Jakabaring Sport City area during the sporting activities, namely the XVIII Asian Games. Measurements were carried out for seven days in the span of the XVIII Asian Games (18 August 2018 - 2 September 2018). Sampling was carried out in nine sports facilities and all residential facilities located at Jakabaring Sport City (athletes homestead, rental apartments, and apartments), according to the distribution of MSW containers in each facility. The MSW generation rate is obtained by dividing the total volume of waste by total visitors and the day of use of sports or residential facilities. While the composition of MSW (in the wet weight fraction) is divided into organic waste and inorganic waste (plastic, paper and residue). The measurement results show differences in the rate of MSW generation between sports facilities and residential facilities in the Jakabaring Sport City area. In sports facilities, MSW generation rate is measured at $0.0329 \mathrm{~kg} / \mathrm{person} /$ day with the composition of MSW dominated by organic waste $(=59.19 \%)$. The measured density of MSW in sports facilities was $525.80 \mathrm{~kg} / \mathrm{m}^{3}$. Whereas in residential facilities, the MSW generation rate is measured at $0.7255 \mathrm{~kg} / \mathrm{person} / \mathrm{day}$, with the composition of MSW dominated by inorganic waste $\left(=42 \%\right.$ ). The average waste density in residential facilities is $270.57 \mathrm{~kg} / \mathrm{m}^{3}$. The rate of MSW generation in residential facilities is higher than the rate of MSW generation in the sports area, may be due to differences in usage hours of the two types of facilities. Further research is needed on the rate of waste generation per hour of use in sports facilities during a sporting event in the region.
\end{abstract}

Keywords: Composition, Generation Rate, MSW, Sports Facilities

\section{Introduction}

Jakabaring Sport City is an integrated sports area of 325 hectares that has twenty sports venues along with supporting facilities, located in the Seberang Ulu area (about five $\mathrm{km}$ from the center of Palembang City). This area is an area for organizing international standard sports activities which are participated in by many countries such as ASIAN Games, SEA Games and other international sports activities. An increase in the number of visitors occured during sports events which then triggered an increase in MSW generation in this area.

According to Damanhuri and Padmi (2016), the rate of MSW generation varies according to the source of MSW (Table 1). In the sport areas, there are results of measurements of the rate of MSW generation in the Gelora Bung Karno, Jakarta; sports areas in Thailand; and waste generation in New Tottenham Hotspur Football Club (THFC) Stadium. In the Gelora Bung Karno, that has the same characteristics as the Jakabaring Sport City, but does not have 
residential facilities, the rate of waste generation during the activities in the Gelora bung Karno area is 0.000857 $\mathrm{kg} /$ person/day [1]. While the rate of MSW generation at soccer match in Thailand is $0.097 \mathrm{~kg} /$ person/match [2]. And also MSW generation for five events (one game for sure in one day) at New Tottenham Hotspur Football Club (THFC) Stadium that took place ranged from $0.21 \mathrm{~kg}$ and 0.37 $\mathrm{kg} /$ person/game, with the average generation rate measured at $0.25 \mathrm{~kg} /$ person/game [3]. The other result of measurements of the rate MSW generation in the sport area was at sport facility in PT. Semen Padang, the rate of waste generation is 1.181 liter/people/day $(=0.29525 \mathrm{~kg} /$ people/day if the waste density is $250 \mathrm{~kg} / \mathrm{m}^{3}$ ) [4]. The result of the measurement of the rate of MSW generation at College Football Stadium
(Memorial Stadium/Faorot Field) located on Columbia, Mussouri Campus of the University of Missouri is 0.2487 $\mathrm{kg} /$ visitor/game (with capacity for 71,168 and $17.7 \mathrm{mt}$ or $17,700 \mathrm{~kg}$ of waste generation/game) [5]. The result of measurements of the rate MSW generation in the sport area was at sport facility in Campus of UIN Ar-Rainiry area, the rate of generation is $0.0105 \mathrm{~kg} / \mathrm{m}^{2} /$ day while the rate of MSW generation at sport facility in Campus of Bina Widya University of Riau is $0.002 \mathrm{~kg} /$ person/day [6, 7]. The average of waste generation at Skydome baseball stadium in Toronto in 1992 was generated 2,552.04 tons of solid waste by 50,000 spectators per game, then in California, the spectators generated 74.1 tons of solid waste during five days of the $27^{\text {th }}$ Super Bowl in 1993 [8].

Table 1. MSW generation rate based on the source [9].

\begin{tabular}{llll}
\hline Source & Unit & Volume (liter) & Weight (kg) \\
\hline Permanent House & / person/ day & $2.25-2.50$ & $0.35-0.40$ \\
Office & / employee/ day & $0.50-0.75$ & $0.03-0.10$ \\
Shop & / employee/ day & $2.50-3.00$ & $0.15-0.35$ \\
School & / student/day & $0.10-0.15$ & $0.01-0.02$ \\
Market & $/ \mathrm{m}^{2} /$ day & $0.20-0.60$ & $0.10-0.30$ \\
\hline
\end{tabular}

In the residential areas, the result of measurements of the rate of MSW generation in the Residential in Mosul City was $0.496 \mathrm{~kg}-0.519 \mathrm{~kg} / \mathrm{capita} /$ day [10]. Meanwhile, the rate of waste generation in Mekong Delta City, Vietnam; the household solid waste generation is $285.28 \mathrm{~g} /$ capita/day (= $0.28528 \mathrm{~kg} / \mathrm{capita} /$ day), and the rate of waste generation in the Urip Sumoharjo apartment in Surabaya is 0.21 $\mathrm{kg} /$ person/day [11, 12].

The MSW generation during the sporting activities in the Jakabaring Sport City area has never been measured before, so it is necessary to conduct research to measure the generation rate and composition of waste at Jakabaring Sport City. This study aims to measure the generation rate and composition of waste in the Jakabarig Sport City area during Asian Games XVIII (2018), which includes MSW generation generated by sports and residential facilities. According to Damanhuri and Tri Padmi (2016), MSW can be grouped into organic waste (wet waste from kitchen activities) and inorganic waste (dry waste such as bottles, paper and plastic), with the density of MSW at sources ranging from $0.01-0.2$ tons $/ \mathrm{m}^{3}$.

\section{Methodology}

The study was conducted for 7 (seven) days during the Asian Games XVIII event, from August 18, 2018 to September 2, 2018. Measurements of the generation rate and composition of MSW were carried out by directly measuring the volume of MSW in each selected sports and residential facility (Table 2). While the number of visitors and residents is obtained from the Jakabaring Sport City area manager. Sampling is done by dividing the area into 2 (two) facilities, namely sports facilities and residential facilities. Samples are measured from 9 (nine) units of sports facilities and 3 (three) units of residential facilities, according to the location of MSW containers in each facility (Table 2).

The measurement of waste generation in this study was carried out in MSW containers located in the sampling location. Sampling is carried out for 7 (seven) days in each selected sports facility and residential facilities in the Jakabaring Sport City area. Measurements of generation and composition of waste are carried out by measuring the weight of MSW in each waste container according to its components (organic, paper, plastic and residue).

Table 2. Location of Sampling.

\begin{tabular}{ll}
\hline Type of Facility & Name of Facility \\
\hline & Gelora Sriwijaya Stadium \\
& Ranau Sport Hall \\
& Shooting Range \\
& Tennis Stadium \\
Sports & Sport Climbing \\
& Beach Volley \\
& Rowing Center \\
& Bowling Center \\
& Roller Sport Stadium \\
& Athletes Homestead \\
& Rental Apartments \\
Residential & Apartments \\
\hline
\end{tabular}

MSW is a domestic solid waste consisting of organic and inorganic substances which are considered useless and must be managed so as not to endanger the environment, and protect development investments [13]. In the simple terms, MSW is grouped into [9]: (a) organic waste which includes wet waste from kitchen activities, and (b) inorganic waste which includes dry waste such as bottles, paper and plastic. Retrieval of data on the composition of waste measurements was carried out at temporary waste station. 


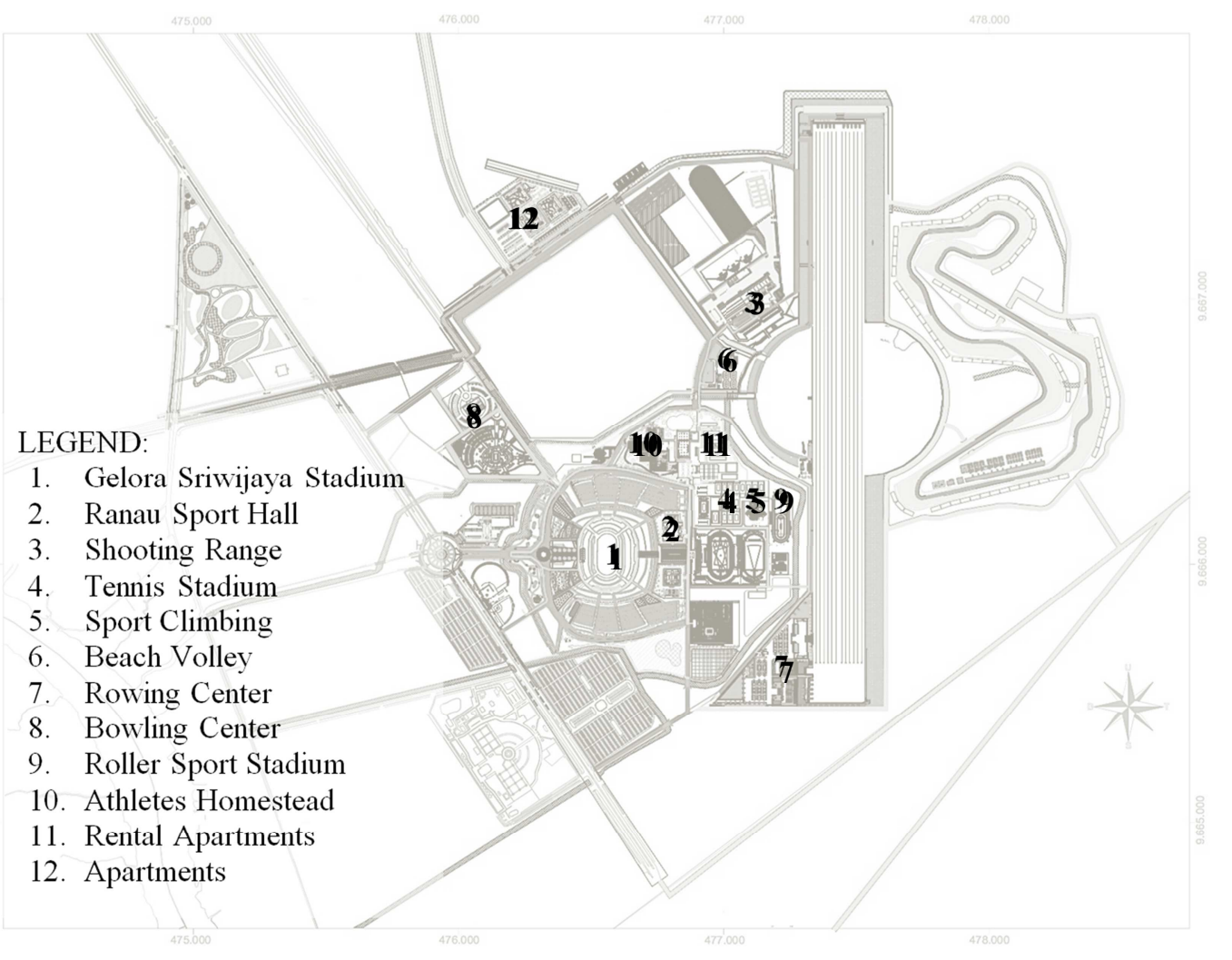

Figure 1. Jakabaring Sport City area.

MSW samples were taken from the containers available at the sampling location "Figure 1". The weight and volume of MSW are recorded, so the generation and density of MSW were measured based on the dimensions and volume of the MSW container. Then, waste composition was expressed as a percentage of wet weight. The sorting of MSW was carried out based on the types of MSW that have been determined (organic, paper, plastic and residue) in every waste container in each sporting and residential facility. Sorted MSW is weighed and recorded according to the type of waste. The MSW fraction (\% of wet weight) for each components was calculated by dividing the total weight (wet) of each MSW component with total weight of MSW [14]. Although MSW was collected and transported every day during the implementation of Asian Games XVIII, but in this study, sampling was carried out in only seven determined days (Table 4 and Table 6).

\section{Result and Discussion}

\subsection{MSW Generation Rate}

The MSW generated by each sports facility in the Jakabaring Sport City area varies according to the number of visitors, residents and types of activities at each facility. Sampling was carried out for 7 (seven) days at each selected sports and residential facilities in the Jakabaring Sport City area. The rate of waste generation was obtained from the weight of the waste in the waste container divided by the (total) number of visitors and occupants at the sampling location.

Table 3. Waste generation rates at the Jakabaring Sport City Sports Facility.

\begin{tabular}{lllll}
\hline No. & Source & Total Weight of MSW (kg) & Total Number of Visitors (person) & MSW Generation Rate (kg/ visitors) \\
\hline 1 & Gelora Sriwijaya Stadium & 240.44 & 60,000 & 0.0040 \\
2 & Ranau Sport Hall & $1,162.15$ & 14,000 & 0.0830 \\
3 & Shooting Range & 609.6 & 11,680 & 0.0522 \\
4 & Tennis Stadium & 980.85 & 31,130 & 0.0305 \\
5 & Sport Climbing & 330.35 & 3,600 & 0.0918 \\
6 & Beach Volley & 281.98 & 11,550 & 0.0244 \\
7 & Rowing Center & 879.55 & 15,050 & 0.0584 \\
8 & Bowling Center & 350.66 & 1,200 & 0.2922 \\
9 & Roller Sport Stadium & 118.9 & 1,600 & 0.0743 \\
Total & & $4,954.48$ & 150,810 & 0.0329 \\
\hline
\end{tabular}

From the results of measurements, the highest MSW generation rate is found in the Bowling Center are $(=0.2922$ $\mathrm{kg}$ /visitor), and the lowest MSW generation rate in Gelora
Sriwijaya Stadium $(=0.0040 \mathrm{~kg} /$ visitor $)$. The average rate of MSW generation from the nine sports facilities is 0.0329 $\mathrm{kg} /$ visitor. This result is similar to the rate of MSW 
generation in offices and shops (Table 1).

The rate of MSW generation in sports facilities in the Jakabaring Sport City was lower than the rate of growth measured at a soccer match in Thailand, in New Tottenham Hotspur Football Club (THFC) Stadium, sport facility in PT. Semen Padang, and College Football Stadium (Memorial Stadium/Faurot Field) located on Columbia, Missouri Campus of the University of Missouri, Skydome baseball stadium in Toronto in 1992 and lower than waste generation in California during five days of the $27^{\text {th }}$ Super Bowl in 1993 $[2,3,4,5,8]$. However the rate of MSW generation of Jakabaring Sport City higher than the rate of MSW generation measured in the Gelora Bung Karno, Jakarta, sport facility in Campus of UIN Ar-Rainiry area, and higher than the rate of MSW generation measured in sport facility in Campus of Bina Widya University of Riau [1, 6, 7]. The high variation in the rate of generation of MSW in each sport facility may be due to differences in usage hour of each facility, this requires further research in the future. For the Bowling Center venue, where the rate of MSW generation is the higherst, there was a tight match schedule in ten hours, longer than other sports facilities.

For residential facilities, the rate of MSW generation at Jakabaring Sport City ranges from 0.2965 - 0.9455 $\mathrm{kg} /$ occupant/day, with a measn MSW generation rate of $0.7255 \mathrm{~kg} /$ occupant/day (Table 4). The rate of MSW generation in residential facilities in the Jakabaring Sport City was higher than residential solid wastes generation rate in Mosul City, and households solid waste generation in a Mekong Delta City, Vietnam, and also higher than the rate of waste generation in the Urip Sumoharjo apartment in Surabaya [10-12].

The highest MSW generation rate was measured in the first day sampling (measurement on 19/08/2018), and the lowest generation rate was found in the sevent day sampling (measurement on 31/08/2019). The rate of MSW generation in residential facilities was similar to the rate of MSW generation in permanent residential house (Table 1).

"Figure 2" shows the decreasing of MSW generation rate in Jakabaring Sport City residential facilities, this is in line with the decline in occupant activities at the facility.

Table 4. MSW generation in residential facilities.

\begin{tabular}{llll}
\hline Day of Measurement & Weight of MSW $(\mathbf{k g})$ & Number of Occupants & MSW Generation Rate (kg/ occupant/ day) \\
\hline Day-1 (19/08/2018) & 2,082 & 2,202 & 0.9455 \\
Day-2 (21/08/2018) & 2,127 & 2,386 & 0.8915 \\
Day-3 (23/08/2018) & 2,082 & 2,482 & 0.8388 \\
Day-4 (25/08/2018) & 2,064 & 2,474 & 0.8343 \\
Day-5 (27/08/2018) & 1,241 & 2,353 & 0.5272 \\
Day-6 (29/08/2018) & 1,241 & 1,985 & 0.6249 \\
Day-7 (31/08/2018) & 528 & 1,781 & 0.2965 \\
Total & 11,364 & 15,663 & 0.7255 \\
\hline
\end{tabular}

\subsection{MSW Density}

The MSW density in each facility were calculated by dividing the total weight of the waste by the volume of waste in the garbage container. MSW density measurements were carried out in four sports facilities and residential facilities (Table 5 and Table 6). The MSW density in a sports facility is measured at $525.80 \mathrm{~kg} / \mathrm{m}^{3}$ while the average waste density in residential facility is measured at $270.57 \mathrm{~kg} / \mathrm{m}^{3}$.

Table 5. MSW density in sports facilities

\begin{tabular}{llll}
\hline Source of MSW & Total Weight of MSW $\mathbf{( k g )}$ & Waste Container Cap. $\left(\mathbf{m}^{\mathbf{3}}\right)$ & Density of $\mathbf{M S W}\left(\mathbf{k g} / \mathbf{m}^{\mathbf{3}}\right)$ \\
\hline Shooting Range & 609.60 & 1.44 & 423.33 \\
Tennis Stadium & 980.85 & 1.44 & 681.15 \\
Sport Climbing & 330.35 & 0.72 & 458.82 \\
Bowling Center & 350.66 & 0.72 & 487.03 \\
Total & $2,271.46$ & 4.32 & 525.80 \\
\hline
\end{tabular}

Table 6. MSW density in residential facilities.

\begin{tabular}{llll}
\hline Day of Measurement & Weight of MSW $(\mathbf{k g})$ & Waste Container Cap. $\left.\mathbf{( m}^{\mathbf{3}}\right)$ & Density of $\mathbf{~ M S W ~}\left(\mathbf{k g} / \mathbf{m}^{3}\right)$ \\
\hline Day-1 (19/08/2018) & 2,082 & 6.00 & 347.00 \\
Day-2 (21/08/2018) & 2,127 & 6.00 & 354.50 \\
Day-3 (23/08/2018) & 2,082 & 6.00 & 347.00 \\
Day-4 (25/08/2018) & 2,064 & 6.00 & 344.00 \\
Day-5 (27/08/2018) & 1,241 & 6.00 & 206.75 \\
Day-6 (29/08/2018) & 1,241 & 6.00 & 206.75 \\
Day-7 (31/08/2018) & 528 & 6.00 & 88.00 \\
Total & 11,364 & 42.00 & 270.57 \\
\hline
\end{tabular}




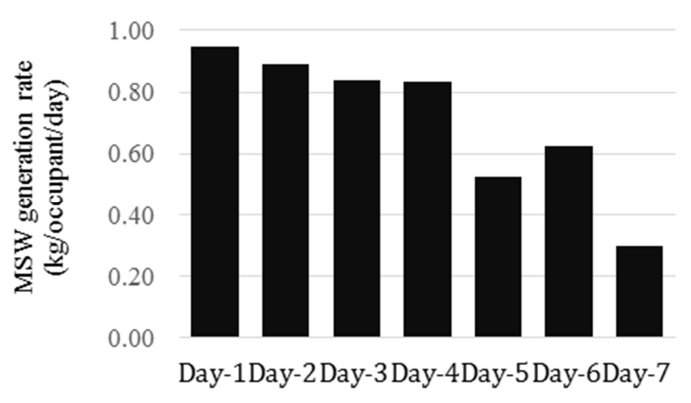

Figure 2. MSW generation at residential facilities at Jakabaring Sport City.

\subsection{MSW Composition}

The measurement of the composition of MSW in the Jakabaring Sport City area is done by sorting MSW into two types of waste, namely: (a) organic waste (from kitchen activities) and, (b) inorganic waste (bottles, paper, plastic and residue). MSW in sports facilities is dominated by organic waste $(=59.19 \%)$, and plastic waste $(=31.56 \%)$. The high organic and plastic components are the effects of food consumption from visitors, and solid waste from food vendors around facilities (Table 7).

Table 7. MSW composition in sports facilities.

\begin{tabular}{lllll}
\hline \multirow{2}{*}{ Source of MSW } & \multicolumn{2}{l}{ Weight of MSW $(\mathbf{k g})$} & & Residue \\
\cline { 2 - 3 } & Organic Waste & Pnorganic Waste & 0.00 \\
\cline { 2 - 4 } & & Plastic & 0.73 & 57.21 \\
\hline Gelora Sriwijaya Stadium & 181.01 & 58.70 & 42.60 & 111.40 \\
Ranau Sport Hall & 944.24 & 118.10 & 14.10 & 29.74 \\
Shooting Range & 445.60 & 38.50 & 0.00 & 21.47 \\
Tennis Stadium & 397.98 & 553.13 & 10.92 & 20.28 \\
Sport Climbing & 242.20 & 55.76 & 0.00 & 141.31 \\
Beach Volley & 135.20 & 126.50 & 10.20 & 0.00 \\
Rowing Center & 229.09 & 516.95 & 0.00 & 0.00 \\
Bowling Center & 308.90 & 41.76 & 0.00 & 381.41 \\
Roller Sport Stadium & 59.20 & 59.70 & 78.55 & $7.67 \%$ \\
Total & $2,943.42$ & $1,569.10$ & $1.58 \%$ & \\
MSW fraction & $59.19 \%$ & $31.56 \%$ & & \\
\hline
\end{tabular}

While Table 8 shows that the composition of waste in residential facilities in residential facilities in the Jakabaring Sport City area was also dominated by organic waste $(=42 \%)$, followed by plastic waste $(=33 \%)$ and paper waste $(=24 \%)$. The waste composiiton in this residential facility is relatively the same as the MSW component which is dominant in residential area at Palembang city, which is $38.3 \%$ organic waste [15].

Table 8. MSW composition in residential facilities.

\begin{tabular}{lllll}
\hline \multirow{2}{*}{ Source of MSW } & \multicolumn{2}{l}{ Weight of MSW $(\mathbf{k g})$} & & \\
\cline { 2 - 5 } & Organic Waste & Inorganic Waste & Paper & Residue \\
\cline { 2 - 5 } & $4,752.00$ & $3,762.00$ & $2,730.00$ & 120.00 \\
Residential facilities & $41.82 \%$ & $33.10 \%$ & $24.02 \%$ & $1.06 \%$ \\
\hline
\end{tabular}

If the weight of the waste per component in sports and residential facilities is combined, it can be seen that MSW in the Jakabaring Sport City area was dominated by organic waste $(=47.11 \%)$, followed by plastic waste $(=32.63 \%)$ and paper waste $(=17.19 \%)$, see "Figure 3 ".

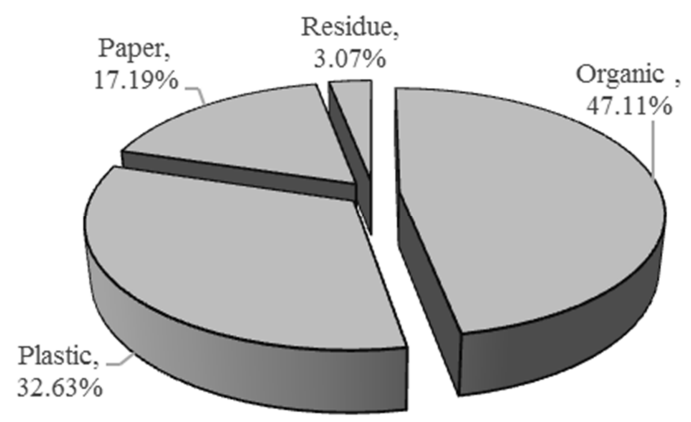

Figure 3. MSW composition in Jakabaring Sport City.

\section{Conclusion}

Based on the results of the research during the implementation of Asian Games XVIII at Jakabaring Sport City, the measured MSW generation rate in sports facilities was $0.0329 \mathrm{~kg} /$ visitor, which was dominated by organic waste $(=59.19 \%)$ and plastic waste $(=31.56 \%)$. Whereas in residential faciliies, the MSW generation rate was measured at $0.7255 \mathrm{~kg} /$ occupant/day, which is also dominated by organic waste $(=42 \%)$, followed by plastic waste $(=33 \%)$ and papaer waste $(=24 \%)$. MSW density in sports and residential facilities is $525.8 \mathrm{~kg} / \mathrm{m}^{3}$ and $270.57 \mathrm{~kg} / \mathrm{m}^{3}$ respectively. If the weight of the waste per component in sports and residential facilities is combined, the MSW in the Jakabaring Sport City area was dominated by organic waste $(=47.11 \%)$, followed by plastic waste $(=32.63 \%)$ and paper 
waste $(=17.19 \%)$. The high component of organic waste, plastic and paper produced during the sporting events, requires further research to determine the type of processing that is most suitable for this sporting are. But, there is still a high variation in the rate of waste generation in each Jakabaring Sport City sport facility. This may be due to different usage hours at each sports facility, so further research needed on measuring the rate of waste generation per usage hour of sports facilities.

\section{Acknowledgements}

The authors would like to thank the XVIII Asian Games Task Force, Housing and Settlement Area Office of South Sumatra Province, and PT. Jakabaring Sport City which has helped carry out this research.

\section{References}

[1] Pusat Pengelola Kawasan Gelora Bung Karno (PPKBGK) (2017). Senayan. Jakarta.

[2] Atchariyasopon, K. (2017) Sustainable Solid Waste Management in Sports Events: A Case Study of Football Matches in Thailand. Journal of Population and Social Studies, Vol. 25 (1), pp. 69-81.

[3] Seal, Megan P. and Fergus Anderson (2015) New Tottenham Hotspur Football Club (THFC) Stadium, Operational Waste Management Strategy. BuroHappold Engineering. London.

[4] Anwar, Borris A. (2011) Generation Studies, Composition and Potential for Recycling in PT. Semen Padang Area. Faculty of Engineering, university of Andalas. Padang.

[5] Costello, Christine; McGarvey, Ronald G.; and Birisci, Esma. (2017): Achieving Sustainability beyond Zero Waste: A Case Study from a College Football Stadium. Bioengineering Department, University of Missouri. Columbia.
[6] Lingga, Marhaban (2019) The Study of Waste Generation and Composition at Campus of UIN Ar-Rainiry Area. Faculty of Science and Technology. University of Islamic Ar-Rainiry Country. Banda Aceh.

[7] Febria, Sri., Darmayanti, Lita., and Asmura, Jecky (2014). The Study of Waste Generation and Composition for Basic Planning Waste Management Systems at Bina Widya Campus of University of Riau. JOM FTEKNIK Vol. 1 No. 2. Faculty of Engineering. University of Riau. Riau.

[8] Woods, R. (1993). Waste From Stadiums. Waste Age, 87$94 . \quad$ Retrieved from http://inhouse.p2ric.org/ref/09/08938.pdf.

[9] Damanhuri, E. and Tri Padmi (2016) Integrated Waste Management. ITB Press. Bandung.

[10] Hammad, Ammar T. and Sulaiman, Fadia A. (2016): Determination of the Composition and Generation Rates of Residential Solid Wastes in Mosul City. Trikrit Journal of Engineering Sciences; 23 (4): 103-108.

[11] T. Nyuyen P., M. Yasuhiro, F. Takeshi (2010) Household Solid Waste Generation and Characteristic in a Mekong Delta City, Vietnam. Journal of Environmental Management Vol. 91, issue 11. Graduate School of Environmental Science, Okayama University. Japan.

[12] Kusumaningrum, Diah (2011) Evaluation of Environmental Infrastructure Management of Apartment in Surabaya (Case Study: Urip Sumoharjo Apartment). Environmental Engineering, Sepuluh November Institute of Technology. Surabaya.

[13] SNI 19-2454-2002. Procedures for Operational Urban Waste Management Techniques.

[14] SNI 19-3964-1994. Method for Taking and Measuring Samples for Generation and Composition of Urban Waste.

[15] Hadinata, F. (2009) Volume and Composition of Household and Market Waste at Palembang City in 2008. Journal of the Sriwijaya Engineering Vol. 18 (1). 